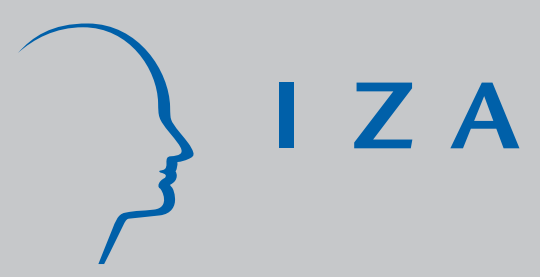

IZA DP No. 2920

Women on the Move:

The Neglected Gender Dimension of the Brain Drain

J ean-Christophe Dumont

J ohn P. Martin

Gilles Spielvogel

J uly 2007 


\title{
Women on the Move: The Neglected Gender Dimension of the Brain Drain
}

\author{
Jean-Christophe Dumont \\ OECD \\ John P. Martin \\ OECD and IZA \\ Gilles Spielvogel \\ OECD
}

Discussion Paper No. 2920
July 2007

IZA

P.O. Box 7240

53072 Bonn

Germany

Phone: +49-228-3894-0

Fax: +49-228-3894-180

E-mail: iza@iza.org

\begin{abstract}
Any opinions expressed here are those of the author(s) and not those of the institute. Research disseminated by IZA may include views on policy, but the institute itself takes no institutional policy positions.

The Institute for the Study of Labor (IZA) in Bonn is a local and virtual international research center and a place of communication between science, politics and business. IZA is an independent nonprofit company supported by Deutsche Post World Net. The center is associated with the University of Bonn and offers a stimulating research environment through its research networks, research support, and visitors and doctoral programs. IZA engages in (i) original and internationally competitive research in all fields of labor economics, (ii) development of policy concepts, and (iii) dissemination of research results and concepts to the interested public.
\end{abstract}

IZA Discussion Papers often represent preliminary work and are circulated to encourage discussion. Citation of such a paper should account for its provisional character. A revised version may be available directly from the author. 


\section{ABSTRACT}

\section{Women on the Move: The Neglected Gender Dimension of the Brain Drain*}

Two trends in international migration flows have attracted much attention recently: (i) the growing feminisation of migration flows; and (ii) the increasing selectivity of migration towards the highly skilled, which in turn has given rise to renewed concerns about the "brain drain" consequences for the sending countries. The two issues have not been considered jointly, however, mainly due to the lack of relevant data. This paper addresses this shortcoming by looking at the gender dimension of the brain drain, based on a new comparable data set that has been collected by the OECD and which allows us to identify people by country of residence, place of birth, gender and level of education. The evidence summarized in this paper shows that female migration to OECD countries has been increasing significantly in recent decades, so that migrant stocks are now more or less gender-balanced. A more surprising result is that this is also true for the highly skilled. Taking into account the fact that women still face an unequal access to tertiary education in many less developed countries, it appears that women are over-represented in the brain drain. This result is reinforced by econometric estimates showing that emigration of highly skilled women is higher, the poorer is their country of origin. This effect is also observed for men but to a lesser extent. It is not observed, however, at lower educational levels, where the traditional migration hump is identifiable. Econometric estimates also report a negative impact of emigration of highly skilled women on three key education and health indicators: infant mortality, under-5 mortality and secondary school enrolment rate by gender. These results raise concerns about a potentially significant negative impact of the female brain drain on the poorest countries.

JEL Classification: F22, J16, J61, O15

Keywords: international migration, gender dimension, brain drain

Corresponding author:

John P. Martin

OECD

Directorate for Employment, Labour and Social Affairs

2, rue André Pascal

F-75775 Paris Cedex 16

France

E-mail: John.Martin@oecd.org

\footnotetext{
* We are grateful to Georges Lemaitre and Martine Durand for helpful comments. The views expressed are our own and cannot be held to be those of the OECD or its member governments.
} 


\section{Introduction}

Two trends in international migration flows have attracted much attention recently: (i) the growing feminisation of migration flows; and (ii) the increasing selectivity of migration towards the highly skilled, which in turn has given rise to renewed concerns about the "brain drain" consequences for the sending countries. The two issues have not been considered jointly, however, mainly due to the lack of relevant data. This paper addresses this shortcoming by looking at the gender dimension of the brain drain, based on a new comparable data set that has been collected by the OECD and which allows us to identify people by country of residence, place of birth, gender and level of education.

As Oso and Garson (2005) noted, migration of women has tended to be overlooked in the literature for many years, the typical migrant being viewed as male. However, the situation has changed recently, reflecting the importance of family reunification flows and the growth of international recruitment in the service sector, notably in domestic services. As a result, there has been much greater interest in the role of migrant women and a new literature has emerged which stresses the role of women as primo-migrants and considers the impact on their children left behind (e.g. Ehrenreich and Hochschild 2002; Parreñas 2001). The specific role of immigrant women in remittances' flows and their uses is also being considered (World Bank 2007).

In the meantime, the literature on the brain drain has evolved significantly, taking in turn more positive or negative views on the effects of the international mobility of the highly skilled on origin countries (Dumont and Lemaître 2005). Recently, several authors have argued the case for a more positive view of the brain drain in terms of an increasing rate of return to education and incentives to train in sending countries. This hypothesis is controversial on both theoretical and empirical grounds (Commander et al., 2004; Docquier and Rapoport, 2007). More generally, one could also argue that it neglects the gender dimension of international migration which may be a major oversight in the light of research showing that highly educated women make a distinctive contribution to the social and economic development of developing countries (World Bank 2001). They play a key role in the education and health sectors, which are critical for development. Moreover, more educated women tend to have fewer children, contributing to lower the fertility rate. The education of mothers also has a positive impact on human capital accumulation (education and health) of their offspring (e.g. Schultz 1995).

As far as policies are concerned, a better understanding of the gender dimension of the brain drain would be of great interest for both origin and receiving countries. Migration and development policies do indeed 
impact both the gender composition of migration flows and the contribution of women to the economic and social development of their home country. ${ }^{1}$

The paper is organised as follows. The first section paints a statistical picture of the importance of women in migration stocks and flows to OECD countries. The second section reviews the distribution by education levels of migrant women in OECD countries. The third section presents new evidence on the gender dimension of the brain drain and its main determinants. The fourth section looks at the impact of the brain drain by gender on key development indicators. The final section draws some conclusions.

\footnotetext{
${ }^{1}$ These issues were emphasised notably by the World Bank’s Chief Economist, François Bourguignon, at the UN General Assembly High-Level Dialogue on International Migration and Development (September 2006, New York).
} 


\section{Women on the move}

According to the new data compiled by the OECD, around the year 2000, there were almost 39 million immigrant women aged 15 and over living in OECD countries (see Box 1). The main regions of birth of immigrant women are the OECD itself (17 millions), South and Central America and the Caribbean (9.4 millions), Asia (8.4 millions) and Africa (3.2 millions).

\section{Box 1: OECD international migration database on immigrants and expatriates}

Data by place of birth, gender and educational attainment are extracted from the OECD International Migration Database. See OECD (2007) for further details. This dataset comprises detailed information on the population aged 15+ around the year 2000 for 28 OECD countries (Korea and Iceland are not included) and more than 200 countries or regions of birth. The database includes information on educational attainment, gender, age, duration of stay, labour market status, occupation, sector of activity and field of study of foreign-born and native-born.

The OECD International Migration Database has been computed mainly from population censuses and population registers. For some countries and variables, however, labour force surveys have been used to complement these sources. This is the case, for instance, in the gender dimension for the Netherlands and Germany.

Education levels are defined according to the International Standard Classification of Education (ISCED). Three levels are distinguished: ISCED 0/1/2: Less than upper secondary; ISCED 3/4: Upper secondary and post-secondary non-tertiary; and ISCED 5/6: tertiary.

Women represent on average 51\% of the total foreign-born population of OECD countries in 2000. More precisely, for all receiving countries except four (Germany, Mexico, Spain and Greece), ${ }^{2}$ immigrant women are more numerous than men (see Chart 1). In Japan, the United Kingdom and Italy, more than 53\% of immigrants are women. The figures are even higher in some Central and Eastern European countries, although this is mainly due to the age structure of their immigrant population.

\footnotetext{
${ }^{2}$ In Germany, Spain and Greece, 2005 Labour Force Survey data show that women are now representing a higher percentage of the foreign-born than males. This is due to the size and the shift in composition of recent migration waves. In southern European countries, for instance, labour migration accounts for the bulk of the flows and targets notably the domestic sectors where women tend to be predominant.
} 


\section{Chart 1. Share of women in the immigrant population in OECD countries, Percentages , circa 2000}

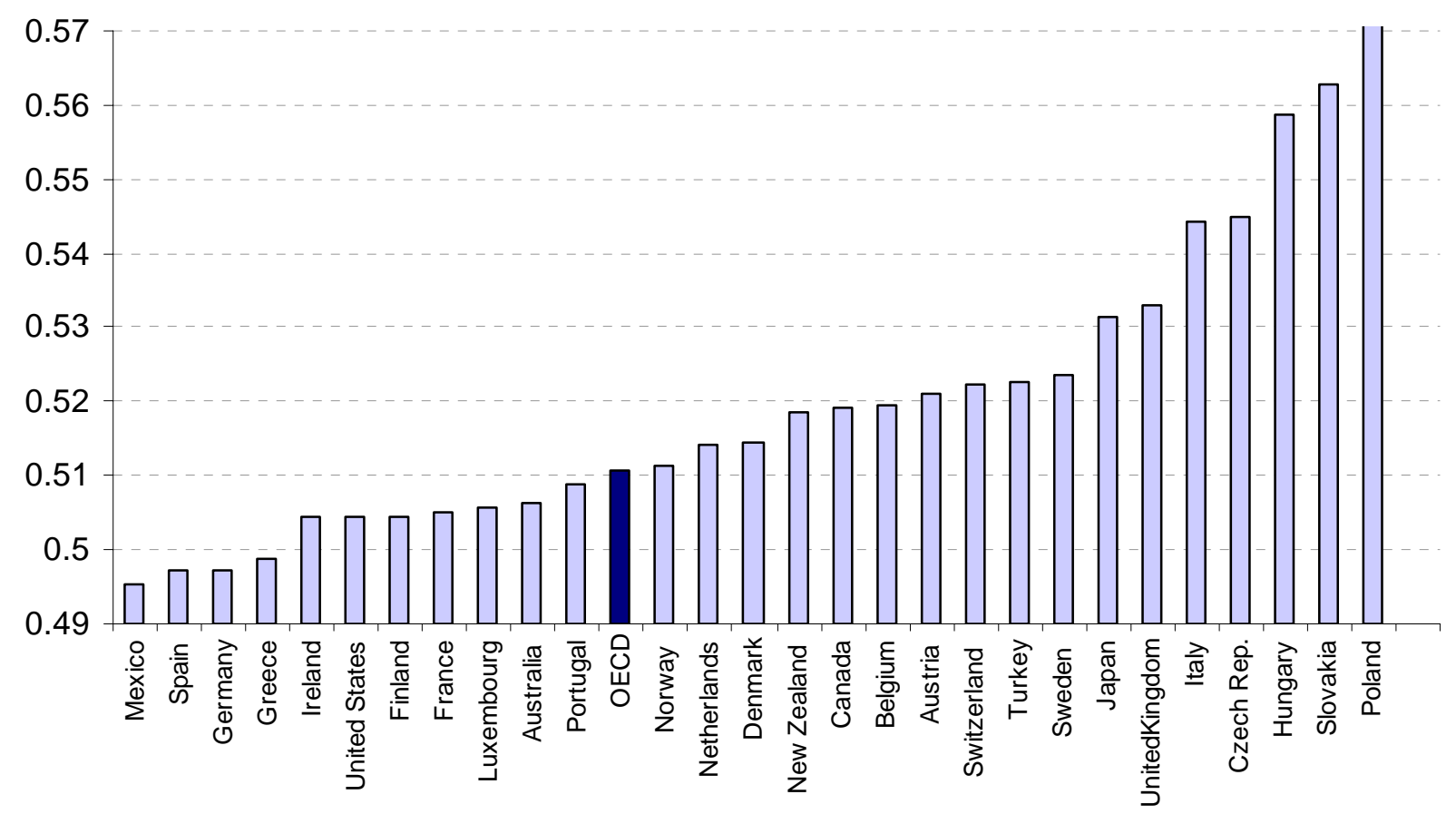

How has the share of women in migration to OECD countries changed over time? Estimates by the United Nations (2006) presented in Chart 2 indicate that, for the world as a whole, the share of women among immigrants has risen slowly from $47 \%$ in the early 1960 s to almost $50 \%$ in 2005 . The same trend has been observed for the most developed countries, as defined by the United Nations (Europe, Northern America, Japan, Australia and New Zealand): 49\% in 1960 and 52\% in 2005. This evolution is even stronger for Europe alone, with an increase of 5 percentage points in the share of women among the foreign-born population over the same period. On the contrary, in Northern America, after a sharp increase between 1960 and 1980, the share of women in the foreign-born population has decreased by almost 3 percentage point between 1980 and 2005. 
Chart 2. Evolution of the share of women in the migrant population by main region, $1960-2005$

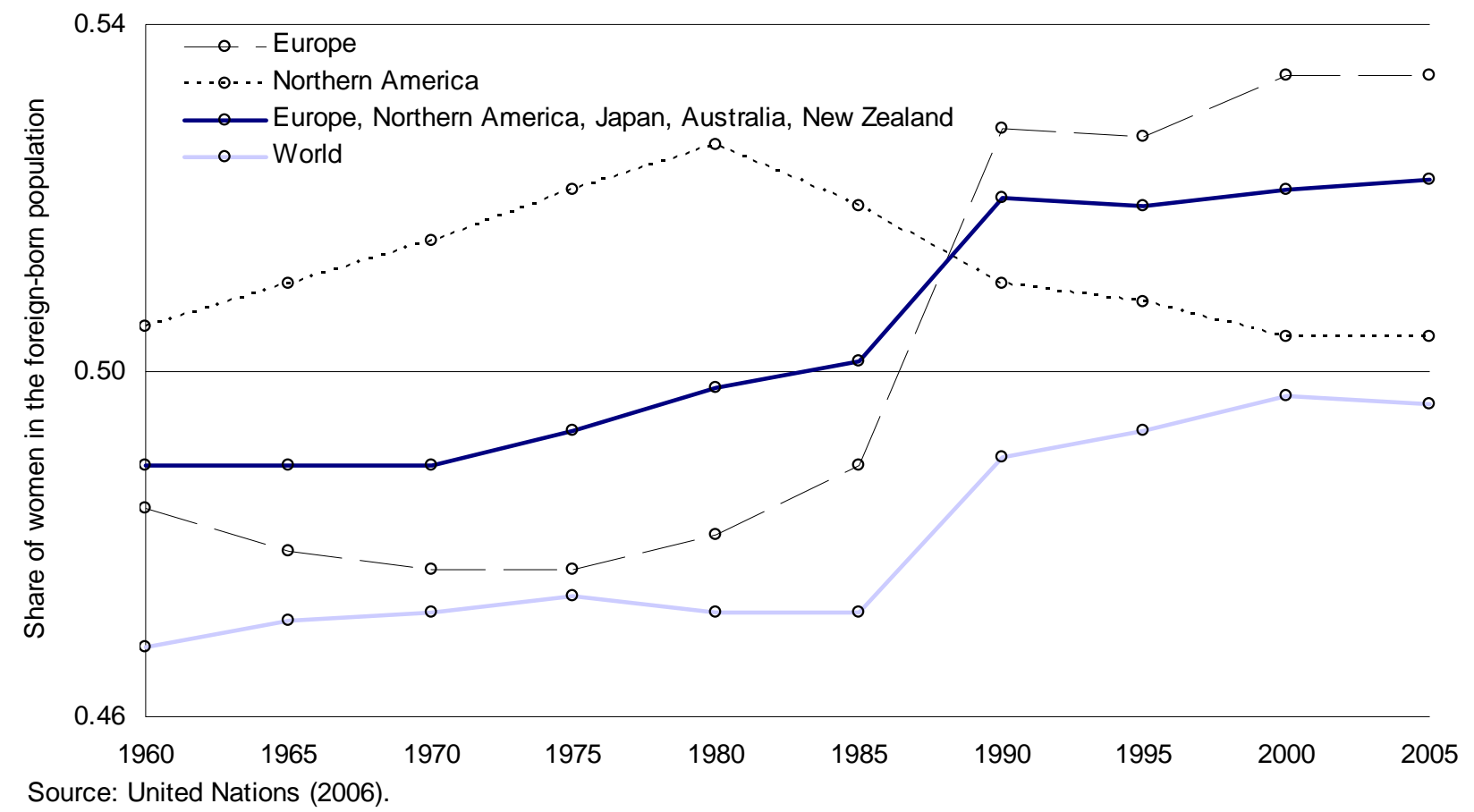

Chart 3. Evolution of the share of women in the foreign-born population in selecetd OECD countries, 1900-200

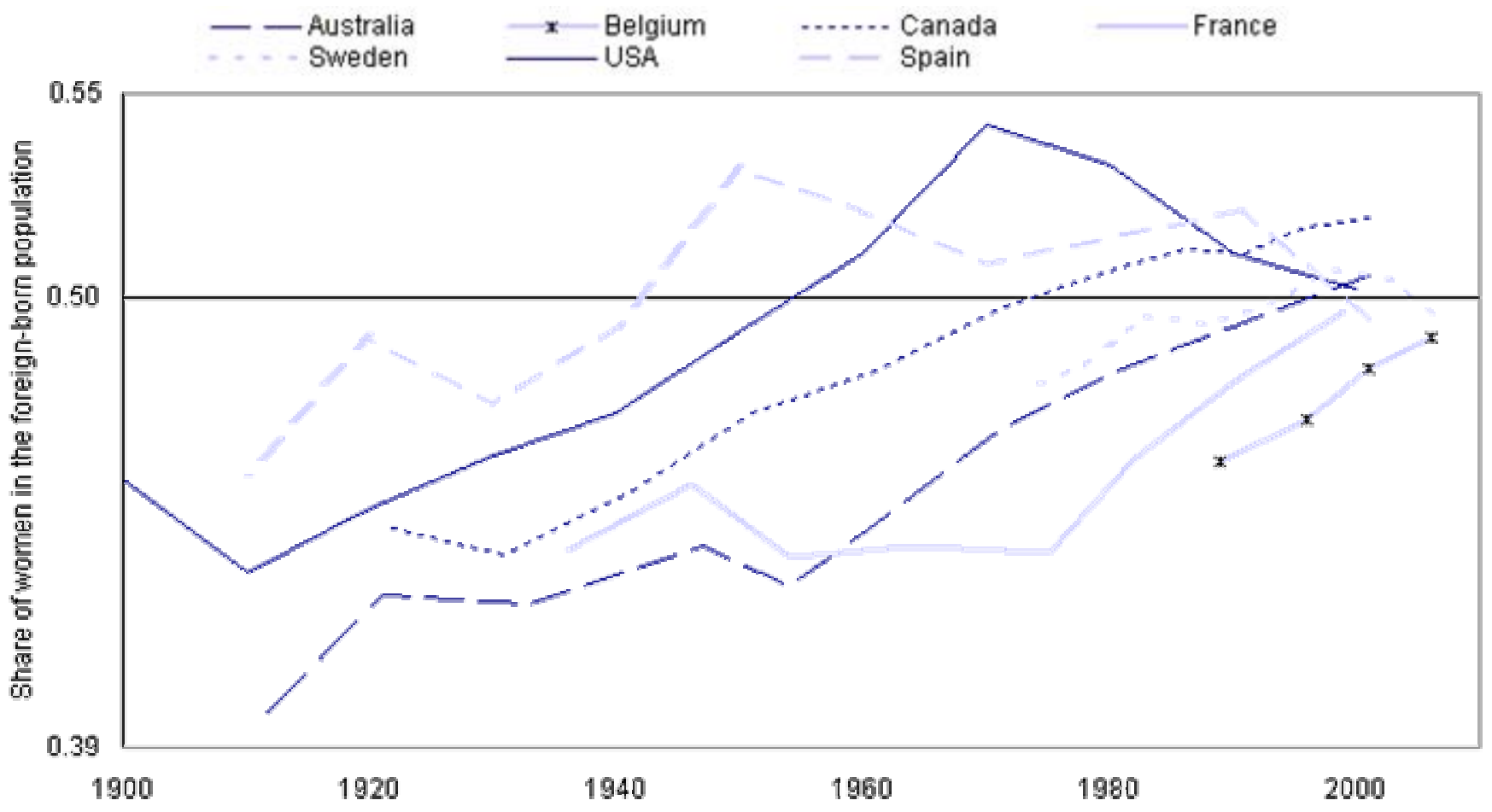

Source: OECD censuses, authors' calculations.

Note: for Sweden and Belgium, data refer to foreigners instead of foreign-born. 
For some OECD countries where population censuses are available over a long period, it is possible to chart a long time series of the share of women among immigrants, going back to 1900 (see Chart 3). Such data from Australia, Canada, Spain and the United States show that the share of women among immigrants at the beginning of the $20^{\text {th }}$ century was low, illustrating a male-dominated migration pattern. ${ }^{3}$ For all seven countries shown in the Chart, women migration rose gradually during the $20^{\text {th }}$ century. ${ }^{4}$ The increase starts later in France than in most other countries and corresponds to the opening up of family migration. In Canada and Australia, the rise has been quite steady since at least 1930, including after the implementation of selective migration policies. For Sweden, a moderate decline in the share of women is observed in the most recent years, after a steep increase from 1973 to 1998.

In the United States, the percentage of women increased until 1970 but started to decline afterwards. This trend partly reflects a changing pattern in the country of origin of migrants: while European migrants represented $75 \%$ of the foreign-born population of the country in 1960, they accounted for only $16 \%$ in 2000. During the same period, the share of Asian immigrants rose from 5\% to $26 \%$ and that of Latin American immigrants from $9 \%$ to $44 \%$ (Mexican immigrants alone accounting for almost 23\% in 2000, against 6\% in 1960). Although the gender mix of the recent European migration to the United States is balanced - with an equal share of men and women - this is not the case for the inflows from Asia and Latin America. The gender balance among migrants from Asian countries is tilted slightly in favour of women (52\% on average), while the share of women among Latin American migrants is below 50\%, with the most recent inflows being even more masculine ${ }^{5}$.

In sum, this review of the data on the gender dimension of migration stocks and flows highlights two stylised facts. First, looking on average across OECD countries, there is now a rough gender balance in inflows, so in this sense migration inflows mirror the gender mix of the native-born population! Second, the current situation and recent evolution is a break from historical trends when most migrants were male, reflecting a range of factors such as growing family reunification, changing economic structures with the shift to post-industrial economies, and rising female educational attainment in origin countries.

\footnotetext{
${ }^{3}$ Hatton and Williamson (2006) point out that “... in almost every decade between the 1820s and the 1890s, more than three-fifths of immigrants to the United States were males. It appears that those who were less involved in the formal labor market, such as children and females, were less likely to be international migrants, since they were less responsive to labor market conditions ... Emigrants in 1900 were certainly different from those in 1800. Early nineteenth-century migrations often took place as family groups, with those who emigrated intent on acquiring land and settling at some overseas frontier". (p. 79)

${ }^{4}$ This pattern is unchanged when one looks at the relative share of women in the foreign-born population (i.e. compared to the gender mix of the native-born) instead of the absolute share.

${ }^{5}$ Among the migrants who arrived from Latin America between 1995 and 1997, only 46\% were women, this share was 44\% for the 1997-1999 wave and $41 \%$ for those who arrived in 1999-2000. This gender bias is even stronger for Mexican migrants, with respectively $43 \%, 40 \%$ and $37 \%$ of women in the successive waves.
} 


\section{International mobility of highly skilled women}

In recent years, the increasing mobility of the highly skilled has been highlighted as a by-product of the implementation of more selective labour migration policies in OECD countries, notably in Europe, and the increasing demand for skills in general in a context of population ageing.

Perhaps because it has been too readily assumed that spouses in the family migration programmes were mainly women whose qualifications were not selected directly or did not match labour market needs, or that jobs in domestic services, mainly held by recent immigrant women, were not highly qualified, the gender dimension of the international mobility of the highly skilled has been almost entirely neglected. Nonetheless, immigrant women play an important role in the health and long-term care sectors, but also in other highly skilled services. Furthermore, recent research has shown that, even when immigrant women are working in low-skilled occupations, they tend to hold, more often than their male counterparts, higher education qualifications, illustrating a greater exposure to so-called "over-qualification” (Dumont and Monso 2007).

As a matter of fact, if the share of immigrants holding a tertiary degree is higher for men than for women, the differences are not very large (Chart 4), generally below 3 percentage points ${ }^{6}$. In Australia, for instance, highly skilled migration is almost gender-balanced. In the United States, the main receiving country of foreign human capital, $26.6 \%$ of immigrant men had a tertiary degree in 2000 as compared to $25.6 \%$ for immigrant women.

$6 \quad$ The phenomenon of so-called “assortative mating” whereby individuals with high educational qualifications seek spouses with similar characteristics can help account for the fact that while the directly selected part of the migration inflow in countries such as Australia, Canada and New Zealand ranges from 20-25\%, the selection process implicitly extends to a much higher proportion of entering immigrants, principally via the family route. For further details, see OECD (2006, Part II). 


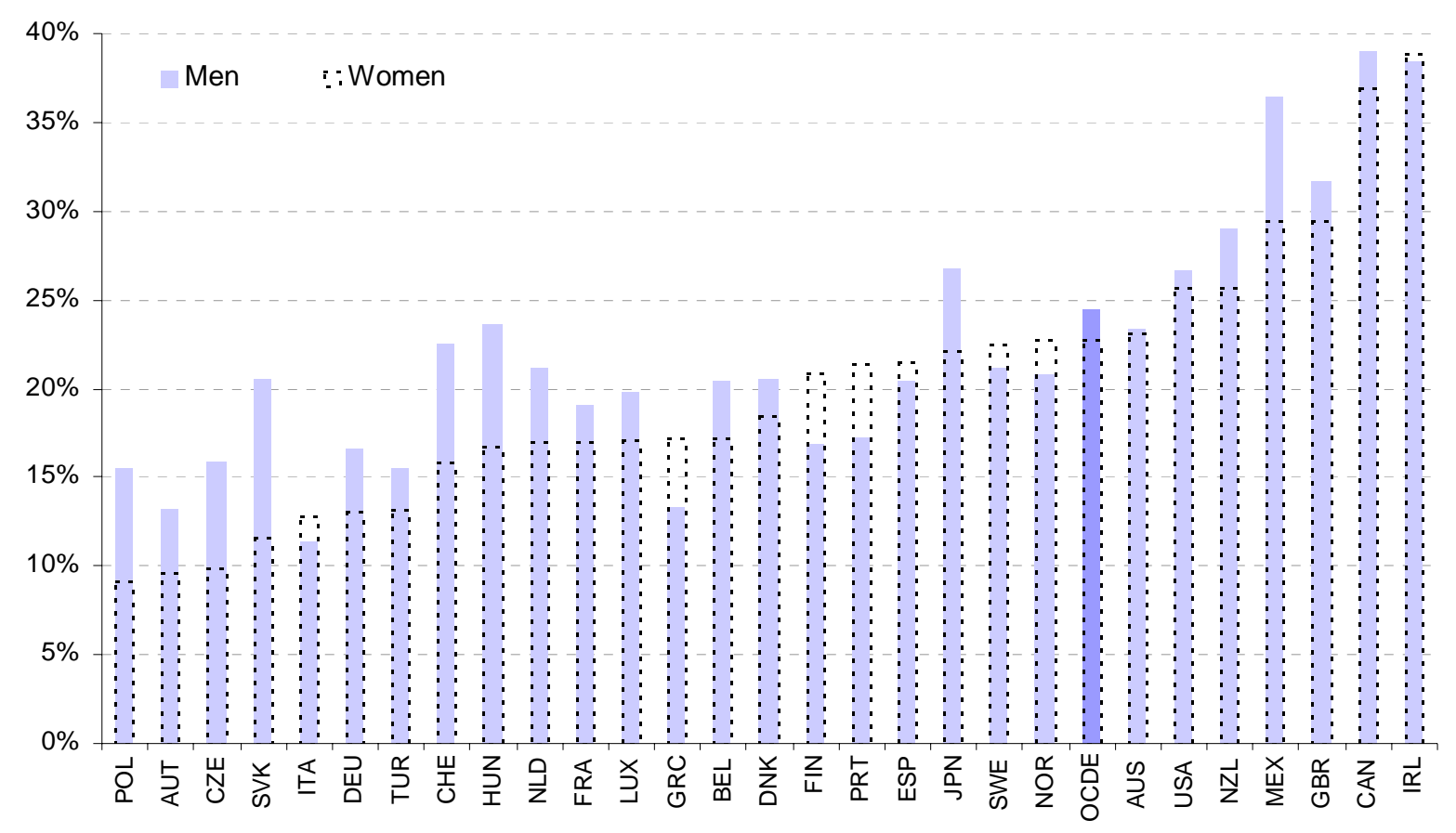

In absolute terms, because of the increasing feminisation of migration inflows mentioned previously, the number of highly skilled immigrant women can outstrip that of their male counterparts. This is the case for instance in the United Kingdom (+44 thousands), in Canada (+22 thousands) and in Sweden (+16 thousands). More surprisingly, this is also true in Italy (+37 thousands) and in Greece (+19 thousands). However, this is not the case for the OECD as a whole, notably because of the relatively low numbers of highly skilled foreign-born women in some important immigration countries such as Germany (-145 thousands) and to a lesser extent France (-48 thousands) and Switzerland (-35 thousands).

Asian migration has dominated highly skilled immigration over the past few decades (OECD 2002). Indian IT specialists and doctors, Filipino nurses or Chinese professionals are emblematic of this phenomenon. Engineers originating from the former USSR are also a significant group among highly skilled immigrants, as well as highly skilled workers from two OECD countries, namely the United Kingdom and Germany. Looking at women, the picture does not change fundamentally except that the Philippines takes the lead and appears as the main origin country for tertiary educated women in OECD countries (see Table 1). 
Table 1. Main origin countries for highly skilled immigrants in OECD countries by gender, numbers, circa 2000(1)

\begin{tabular}{lrrr} 
Country of birth & Female & \multicolumn{1}{l}{ Male } & \multicolumn{1}{l}{ Total } \\
\hline Philippines & 562215 & 325262 & 562215 \\
United Kingdom & 509887 & 565273 & 509887 \\
Former USSR & 506999 & 423151 & 506999 \\
Germany & 440991 & 415688 & 440991 \\
India & 429547 & 570019 & 429547 \\
China & 400495 & 416471 & 400495 \\
Poland & 235147 & 211349 & 235147 \\
Mexico & 234781 & 239291 & 234781 \\
Canada & 217106 & 205061 & 217106 \\
United States & 205847 & 185601 & 205847 \\
France & 199630 & 166184 & 199630 \\
Japan & 157724 & 119744 & 157724 \\
Vietnam & 156349 & 193292 & 156349 \\
Chinese Taipei & 140840 & 122246 & 140840 \\
Jamaica & 122800 & 67912 & 122800 \\
Former Yugoslavia & 118048 & 148780 & 118048 \\
Italy & 114302 & 158884 & 114302 \\
Cuba & 111521 & 109530 & 111521 \\
Iran & 110939 & 171761 & 110939 \\
Romania & 110715 & 115341 & 110715 \\
\hline Total & $\mathbf{8 8 1 2 1 7 3}$ & $\mathbf{9 0 4 1 5 0 3}$ & $\mathbf{8 8 1 2 1 7 3}$ \\
\hline & & & \\
\hline
\end{tabular}

1. Countries are ordered from highest to lowest in terms of the number of highly skilled female immigrants.

Source: OECD censuses, authors' calculations.

\section{The gender dimension of the brain drain}

The fact that there are almost as many highly skilled immigrant women in OECD countries as men, together with the fact that, despite some progress, women face persisting inequalities in access to tertiary education in less developed countries (UNESCO 2004; Wils and Goujon 1998), raises serious concerns in terms of their brain drain.

Combining the OECD International Migration Database to identify immigrants in OECD countries by detailed country of birth and education level, the Barro and Lee (2000) database for the educational structure of the population in origin countries and population data from the United Nations, it is possible to 
compute emigration rates ${ }^{7}$ by educational attainment and gender for just over 100 countries (25 OECD members and 79 non-OECD countries).

Comparing male and female highly skilled emigration rates shows that women are proportionally more likely to emigrate to the OECD. This is true globally, as the average emigration rate of tertiary educated women is $17.6 \%$ as compared to $13.1 \%$ for men, but it also holds for almost all origin countries (see Chart 5). The 5 countries with the highest emigration rates for females are all from the Caribbean except GuineaBissau. They also rank first for male emigration rates.

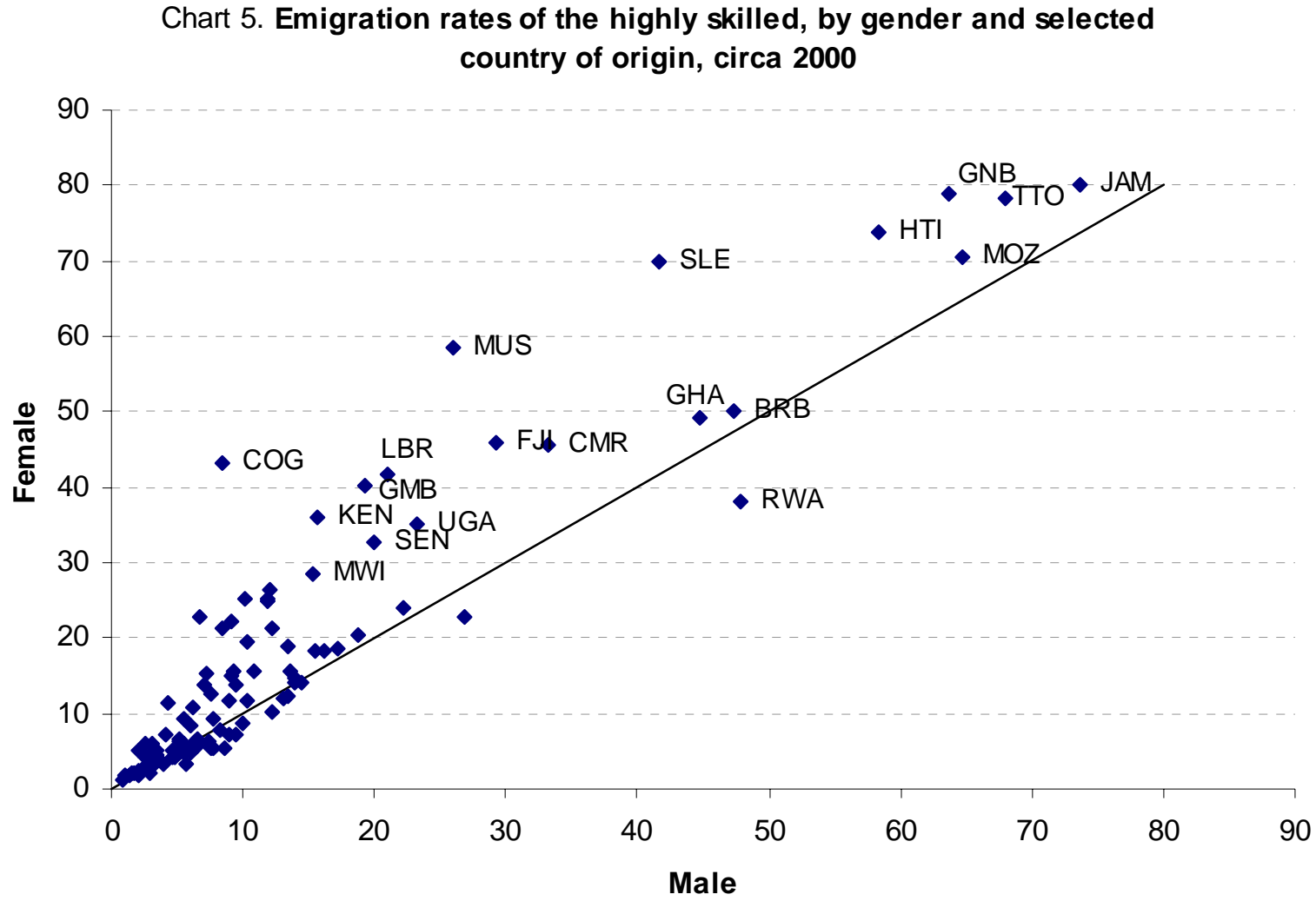

Average emigration rates at the regional level reveal some interesting regularities and differences (see Table 2). In particular, while there is no gender difference in the brain drain for people born in Europe, the gender gap is large for African countries: the average emigration rate is $27.7 \%$ for tertiary-educated women, almost 11 percentage points higher than for tertiary-educated men. A significant gender bias in the

\footnotetext{
${ }^{7}$ The emigration rate for a given country is defined as the ratio of the emigrant population aged 15+ (i.e. people born in this country and living in an OECD country) to the native population 15+ (the emigrants plus the resident population of the country). More formally, let $M_{i e g}$ be the number of migrants of gender $g$, with skill level $e$ born in country $i$ and living in the OECD and $N_{i e g}$ the corresponding non-migrant segment of the population in the origin country (i.e. gender $g$, skill level $e$ and born and living in country $i)$. The emigration rate is then defined as $m_{i e g}=M_{i e g} /\left(M_{i e g}+N_{i e g}\right)$.
} 
emigration rate of the highly skilled is also found for Latin America and Oceania and, to a lesser extent, for Asia.

\begin{tabular}{lrr}
\multicolumn{3}{l}{$\begin{array}{l}\text { Table 2. Average emigration rates, by } \\
\text { region, sex and education, circa }\end{array}$} \\
& Woomen \\
& Women & Men \\
\cline { 2 - 3 } Africa & & \\
Primary education & 0.9 & 1.0 \\
Secondary education & 3.9 & 4.1 \\
Tertiary education & 27.7 & 17.1 \\
Asia & & \\
Primary education & 0.9 & 0.9 \\
Secondary education & 1.9 & 1.6 \\
Tertiary education & 7.3 & 6.1 \\
Europe & & \\
Primary education & 6.5 & 6.4 \\
Secondary education & 7.4 & 6.8 \\
Tertiary education & 10.4 & 9.9 \\
Northern America & & \\
Primary education & 2.1 & 1.6 \\
Secondary education & 3.7 & 2.5 \\
Tertiary education & 3.5 & 4.1 \\
Oceania & & \\
Primary education & 8.5 & 7.0 \\
Secondary education & 9.7 & 10.4 \\
Tertiary education & 23.8 & 16.5 \\
Latin America & & \\
Primary education & 6.6 & 6.5 \\
Secondary education & 13.1 & 12.5 \\
Tertiary education & 21.1 & 17.9 \\
\hline
\end{tabular}

Source: OECD censuses, authors' calculations.

Are there specific country characteristics leading to a greater gender bias in the brain drain? In seeking to answer this question, we estimate the following equation:

$$
\log \left(m_{i e g} /\left(1-m_{i e g}\right)\right)=\mathrm{C}+\alpha \log \left(P O P_{i}\right)+\beta \log \left(G D P p c_{i}\right)+\theta X_{i}+\delta_{e}+\gamma_{g}+\delta_{e} \times \gamma_{g}+\varepsilon_{i e g}
$$

The dependent variable $\log \left(m_{\text {ieg }} /\left(1-m_{\text {ieg }}\right)\right.$ is a logistic transformation of the gender, education and country-specific emigration rate $m_{i e g}$. The covariates are the total population of country $i$ in $2000\left(P O P_{i}\right)$, the average gross domestic product per capita of the country $i$ over the period 1985-2000 in purchasing power parity $\left(G D P p c_{i}\right)$ and a set $X_{i}$ of country-specific indicator variables (the official country language- 
English, French or Spanish - and whether the country is an island). C is the constant term and $\varepsilon_{i e g}$ is an error term.

For each country, we have six emigration rates ( 3 for men and 3 for women, corresponding to the three different education levels). In the pooled estimations, where all the observations are included, dummy variables by levels of education $\left(\delta_{e}\right)$ and gender $\left(\gamma_{g}\right)$ are added. Introducing the interaction term $\delta_{e} \times \gamma_{g}$ implies that the effect of education on the emigration rate can vary by gender. In a second set of regressions, the relation between the emigration rate and country-specific variables are estimated separately for each level of education and gender, leading to a set of 6 independent regressions. In all the regressions, the standard errors were corrected for heteroscedasticity.

The first two regressions in Table 3 refer to the pooled sample: Column 1 includes all countries while Column 2 excludes the OECD countries ${ }^{8}$. They tend to confirm the usual findings according to which emigration rates are higher for smaller countries and islands, but find no robust impact of language or the origin country's level of development ${ }^{9}$ (e.g. Docquier et al. 2007, Dumont and Lemaître 2005). These first estimates also highlight the selectivity of international migration towards the highly skilled. For the nonOECD countries, women holding a secondary degree have a probability to emigrate which is 2 percentage points higher than those with only primary education, while the difference in the emigration rate between tertiary-educated and primary-educated women is much higher at 13 percentage points.

The effect of gender is specifically associated with the level of education, in the sense that women with primary educational attainment do not have a significantly different probability to emigrate than their male counterparts. This is not true, however, for those holding a secondary or a tertiary degree, as illustrated by the statistically significant interaction coefficients between gender and education in the pooled estimations (Columns 1 and 2).

\footnotetext{
${ }^{8}$ Because of their importance with regard to international migration flows, Mexico and Turkey are not excluded from the smaller sample in Column 2.

${ }^{9}$ However, GDP per capita is significant at the $5 \%$ level in the larger sample and Spanish language is significant in the smaller sample (without OECD countries but including Mexico and Turkey).
} 
Table 3. Estimation of the main covariates of the emigration rate by gender and level of education (OLS)

\begin{tabular}{|c|c|c|c|c|c|c|c|c|}
\hline & $\begin{array}{l}\text { (1) } \\
\text { All }\end{array}$ & $\begin{array}{c}(2) \\
\text { All non- } \\
\text { OECD }\end{array}$ & $\begin{array}{c}\text { (3) } \\
\text { Men } \\
\text { Primary }\end{array}$ & $\begin{array}{c}\text { (4) } \\
\text { Women } \\
\text { Primary }\end{array}$ & $\begin{array}{c}\text { (5) } \\
\text { Men } \\
\text { Secondary }\end{array}$ & $\begin{array}{c}(6) \\
\text { Women } \\
\text { Secondary }\end{array}$ & $\begin{array}{c}(7) \\
\text { Men } \\
\text { Tertiary }\end{array}$ & $\begin{array}{c}(8) \\
\text { Women } \\
\text { Tertiary }\end{array}$ \\
\hline Constant & $\begin{array}{l}-1.023 \\
(1.76)\end{array}$ & $\begin{array}{l}-0.303 \\
(2.36)\end{array}$ & $\begin{array}{c}-5.756+ \\
(3.01)\end{array}$ & $\begin{array}{l}-6.532^{\star} \\
(2.71)\end{array}$ & $\begin{array}{l}3.121 \\
(2.96)\end{array}$ & $\begin{array}{l}2.414 \\
(2.23)\end{array}$ & $\begin{array}{l}5.763^{*} \\
(2.19)\end{array}$ & $\begin{array}{l}7.471^{\star \star} \\
(2.39)\end{array}$ \\
\hline Population 2000 (log) & $\begin{array}{c}-0.338^{* *} \\
(0.08)\end{array}$ & $\begin{array}{c}-0.342^{\star *} \\
(0.09)\end{array}$ & $\begin{array}{l}-0.287^{\star} \\
(0.12)\end{array}$ & $\begin{array}{c}-0.279^{*} \\
(0.11)\end{array}$ & $\begin{array}{c}-0.430^{* *} \\
(0.11)\end{array}$ & $\begin{array}{c}-0.348^{\star *} \\
(0.10)\end{array}$ & $\begin{array}{c}-0.367^{* *} \\
(0.08)\end{array}$ & $\begin{array}{c}-0.340^{* *} \\
(0.09)\end{array}$ \\
\hline GDP per cap 85-2000 (log) & $\begin{array}{l}0.209^{\star} \\
(0.09)\end{array}$ & $\begin{array}{l}0.0707 \\
(0.15)\end{array}$ & $\begin{array}{c}0.634^{\star *} \\
(0.20)\end{array}$ & $\begin{array}{c}0.705^{\star \star} \\
(0.18)\end{array}$ & $\begin{array}{c}-0.0125 \\
(0.18)\end{array}$ & $\begin{array}{c}-0.0743 \\
(0.14)\end{array}$ & $\begin{array}{l}-0.291^{*} \\
(0.14)\end{array}$ & $\begin{array}{c}-0.538^{\star \star} \\
(0.16)\end{array}$ \\
\hline Island & $\begin{array}{l}0.911^{*} \\
(0.35)\end{array}$ & $\begin{array}{c}1.229^{\star *} \\
(0.39)\end{array}$ & $\begin{array}{c}1.503^{* *} \\
(0.52)\end{array}$ & $\begin{array}{c}1.661^{\star *} \\
(0.47)\end{array}$ & $\begin{array}{l}1.086^{\star *} \\
(0.40)\end{array}$ & $\begin{array}{l}1.113^{\star \star} \\
(0.39)\end{array}$ & $\begin{array}{l}0.936^{*} \\
(0.37)\end{array}$ & $\begin{array}{r}1.075^{\star \star} \\
(0.37)\end{array}$ \\
\hline Language & & & & & & & & \\
\hline English & $\begin{array}{c}0.0678 \\
(0.26)\end{array}$ & $\begin{array}{l}0.129 \\
(0.30)\end{array}$ & $\begin{array}{l}-0.039 \\
(0.41)\end{array}$ & $\begin{array}{l}0.107 \\
(0.37)\end{array}$ & $\begin{array}{l}-0.273 \\
(0.34)\end{array}$ & $\begin{array}{l}-0.109 \\
(0.29)\end{array}$ & $\begin{array}{l}0.441 \\
(0.29)\end{array}$ & $\begin{array}{l}0.649^{*} \\
(0.32)\end{array}$ \\
\hline Spanish & $\begin{array}{l}0.429 \\
(0.26)\end{array}$ & $\begin{array}{l}0.658^{\star} \\
(0.29)\end{array}$ & $\begin{array}{c}1.186^{* *} \\
(0.41)\end{array}$ & $\begin{array}{c}1.299^{* *} \\
(0.37)\end{array}$ & $\begin{array}{c}1.079^{\star *} \\
(0.35)\end{array}$ & $\begin{array}{c}1.034^{* *} \\
(0.31)\end{array}$ & $\begin{array}{l}-0.359 \\
(0.24)\end{array}$ & $\begin{array}{l}-0.292 \\
(0.27)\end{array}$ \\
\hline French & $\begin{array}{l}0.355 \\
(0.25)\end{array}$ & $\begin{array}{l}0.35 \\
(0.38)\end{array}$ & $\begin{array}{l}0.388 \\
(0.55)\end{array}$ & $\begin{array}{l}0.416 \\
(0.48)\end{array}$ & $\begin{array}{l}0.103 \\
(0.45)\end{array}$ & $\begin{array}{l}0.347 \\
(0.33)\end{array}$ & $\begin{array}{l}0.19 \\
(0.36)\end{array}$ & $\begin{array}{r}0.656+ \\
(0.37)\end{array}$ \\
\hline Education (ref.: primary) & & & & & & & & \\
\hline Secondary & $\begin{array}{l}0.961^{\star *} \\
(0.10)\end{array}$ & $\begin{array}{c}1.220^{\star *} \\
(0.11)\end{array}$ & & & & & & \\
\hline Tertiary & $\begin{array}{c}2.128^{\star *} \\
(0.16)\end{array}$ & $\begin{array}{c}2.595^{\star *} \\
(0.18)\end{array}$ & & & & & & \\
\hline Gender (ref.: men) & & & & & & & & \\
\hline Women & $\begin{array}{c}0.0521+ \\
(0.03)\end{array}$ & $\begin{array}{l}0.0327 \\
(0.04)\end{array}$ & & & & & & \\
\hline $\begin{array}{l}\text { Women * Secondary } \\
\text { Education }\end{array}$ & $\begin{array}{l}0.169^{\star *} \\
(0.05)\end{array}$ & $\begin{array}{c}0.199^{\star *} \\
(0.06)\end{array}$ & & & & & & \\
\hline Women * Tertiary Education & $\begin{array}{c}0.276^{\star \star} \\
(0.06)\end{array}$ & $\begin{array}{c}0.374^{\star \star} \\
(0.06)\end{array}$ & & & & & & \\
\hline Observations & 600 & 450 & 75 & 75 & 75 & 75 & 75 & 75 \\
\hline R-squared & 0.48 & 0.56 & 0.45 & 0.53 & 0.43 & 0.4 & 0.5 & 0.55 \\
\hline
\end{tabular}

Note: Robust standard errors in parentheses; ${ }^{* \star} p<0.01,{ }^{*} p<0.05,+p<0.1$.

Source: OECD censuses, authors' calculations. 
The second set of regressions (Columns 3 to 8) considers the covariates of the emigration rate separately for men and women and different education levels for non-OECD countries. As a result, all coefficients are allowed to vary. Two interesting results need to be emphasised: (i) the effect of the language variable; and (ii) the distinct effect of the origin country's level of development for men and women.

First, it appears that originating from a Spanish-speaking country increases the emigration opportunities for all except the highly skilled. More surprisingly, originating from an English-speaking country does not

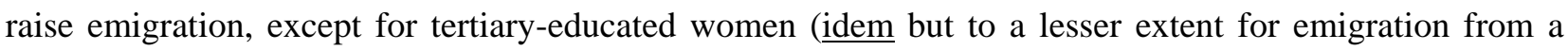
French-speaking country).

Secondly, the level of development, as proxied by GDP per capita in PPPs, has a positive effect on emigration of people with primary education which vanishes at higher levels of education. This effect can be interpreted in relation to the so-called "migration hump" hypothesis, which assumes that increases in income at lower levels can foster international migration as they help to pay for the fixed costs associated with migration (Martin and Taylor 1996). Assuming a sufficiently high return to education, it is therefore possible that this effect does not apply to people with secondary or tertiary education. The estimates in Table 3 tend to support this hypothesis: at higher levels, the GDP per capita variable is negatively correlated to the emigration rate of men and women.

Even more interesting is the fact that, for the highly skilled, the absolute value of the GDP per capita coefficient is higher for women than for men. This means that poorer countries are more affected by the emigration of highly skilled women. One possible explanation is that in the poorest countries, the opportunities for highly educated women are much narrower than for men, because of higher gender inequalities, leading to higher potential returns from migration for women ${ }^{10,11}$. This effect may be supplemented by a pull effect associated to the fact that women tend to be concentrated in sectors (notably education, health) for which the demand is particularly high in OECD countries.

In order to illustrate the relationship between the level of development of the origin country and emigration rates, we produce kernel regression estimates for expatriation rates with GDP per capita "normalized" to

\footnotetext{
${ }^{10}$ For a discussion of this argument, see for instance in United Nations (2005) the chapter on "Gender equality and international migration”.

11 To test this hypothesis, different variables were included as a determinant of the emigration rate : the Gender-Related Development Index (GDI is a composite index which aims at reflecting the inequalities between men and women in life expectancy, knowledge and earned income), the Gender Empowerment Measure (GEM is a composite index focusing on gender inequality in political participation, economic participation and power over economic resources), the gender difference in the tertiary enrolment rate and the relative participation rate of males and females. None of these variables was significant in any regression when GDP per capita is included. One possible explanation is that if gender inequalities affect (positively) the incentive to emigrate, they also affect (negatively) emigration potential (access to decision making, networks, resources ...). The GDI and GEM measures were taken from UNDP (2002).
} 
the US GDP ${ }^{12}$. This is done by gender and level of education. As noted by Cogneau and Gubert (2005) for the total emigration rate, Chart 6a shows a clear migration hump for people with primary or secondary education. Furthermore, emigration increases with the educational level and no significant differences are identifiable by gender. This is not the case at higher education levels. Chart $6 \mathrm{~b}$ shows a decreasing relationship between the emigration rate and development level, as proxied by GDP per capita relative to the US level, for poorer countries. This effect is strong enough to more or less eliminate the migration hump and is more marked for women than for men.

${ }^{12}$ Because of the small sample size, these estimates should be considered with caution. 
Chart 6. Emigration rate by gender and level of education and by "normalized" GDP per capita of the origin country (a), circa 2000

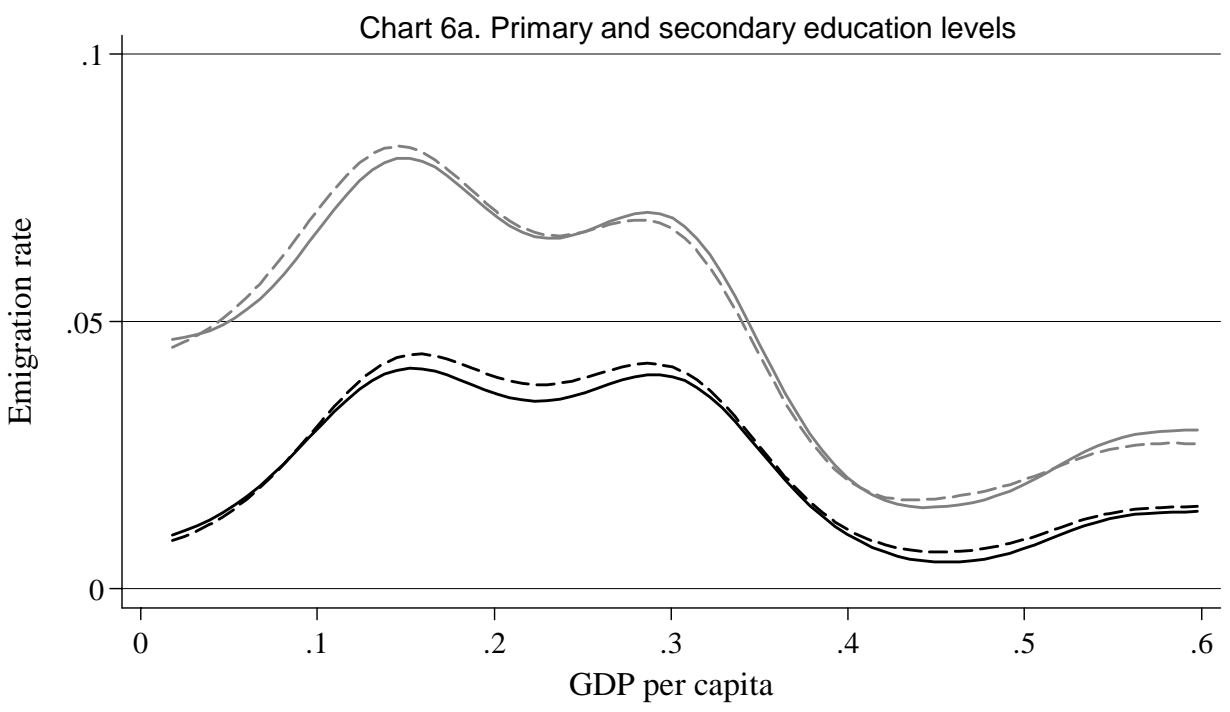

- Men, primary education

- - - Women, primary education

- Men, secondary education - - - Women, secondary education

(a) GDP per capita (1985-2000) divided by the US GDP per capita.

Source: OECD censuses, authors' calculations.

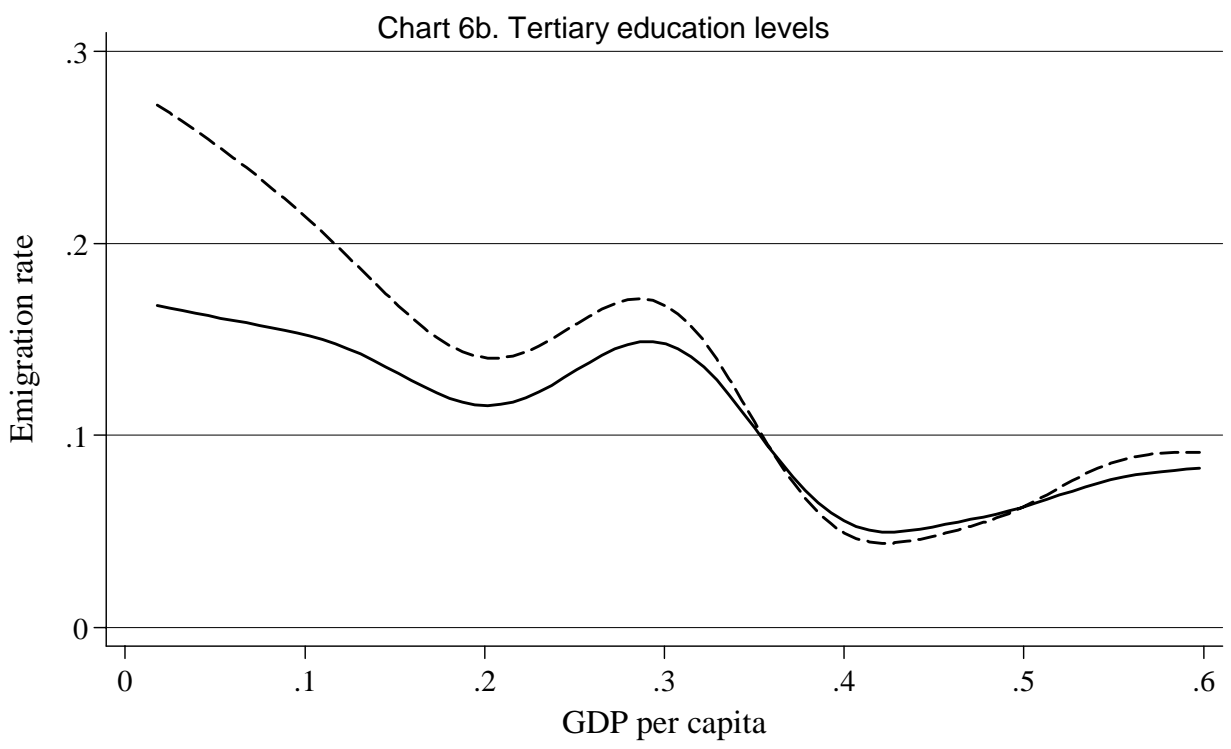

— Men, tertiary education $\quad$ - - - Women, tertiary education 


\section{Impact of the brain drain on origin countries: is there is a gender effect?}

Because of their key contribution to economic and social development, emigration of tertiary-educated women may have a distinctive impact on origin countries. This argument is tested on three basic education and health indicators: infant mortality, under-5 mortality and secondary school enrolment rate by gender. Controlling for GDP per capita, Table 4 shows the impact of global emigration rates by level of education and of the difference by gender in emigration on these key development indicators.

In all regressions, a significant and negative developmental impact of the differential emigration rate of tertiaryeducated women, as compared to men, is found. This means that for comparable levels of brain drain, the more it focuses on women, the higher will be the negative impact on origin countries. This is not the case at lower educational levels, where no significant impact or gender differences are identified. Emigration of women with primary education indeed impacts positively on some of the education and health indicators (see columns 3 and 4). In the latter case, the effect is only weakly significant.

One possible hypothesis to account for these results would be in terms of a balance between the negative brain-drain effects of emigration and the positive developmental effects due to remittances. For primary-educated women, our results might suggest that the latter would outstrip the former. For highly skilled women, the negative impact of absence on remaining family members and communities, often emphasised in the literature, would not on the contrary be compensated for by remittances. Furthermore, the fact that the effects come through "gender differences in emigration" rather than "total emigration rates" could emphasise the specific role of tertiary-educated women as compared to men in rising children and differences in uses of remittances between men and women. But further work is needed to test the soundness of this hypothesis. 
Table 4. Impact of the emigration rate by gender and education level on key development indicators in non-OECD countries (OLS)

$(1)$

Infant mortality rate
(2)

Under-5 mortality rate
(3) Female secondary
enrollment rate

$-146.3^{* *}$

(23.00)

25.82 **

(2.80)

\subsection{6}

(54.40)

355.5+

(178.00)

(127.00)

$-724.6+$

(427.00)

(252.00)

$-79.6$

(85.20)

$-128.9$

(107.00)

(63.00)

7.514

(6.84)

$105.7^{* *}$

(38.30)
13.53

(11.60)

233.0**

(64.80)
$-6.617$

(34.60)

146.3

(114.00)

2.033

(6.41)

$-73.61+$

(37.00)
(4) Male secondary enrollment rate

$-112.6^{* *}$

(21.70)

21.66**

(2.64)

38.15

194.1

(168.00)

Difference between women - men

$74 \quad 74$

52

$-18.34$

$190.1+$

(108.00)

Observations

0.76

0.77

0.82

5.886

$-93.17 *$

(34.90)

Note: Robust standard errors in parentheses; ${ }^{*} p<0.01,{ }^{*} p<0.05,+p<0.1$.

Source: OECD censuses, authors' calculations. Infant mortality rates, Under-5 mortality rates and Secondary enrollment rates by gender are all for 2000 (World Development Indicators). 


\section{Conclusions}

The evidence summarized in this paper shows that female migration to OECD countries has been increasing significantly in recent decades, so that migrant stocks are now more or less gender-balanced. A more surprising result is that this is also true for the highly skilled. Taking into account the fact that women still face an unequal access to tertiary education in many less developed countries, it appears that women are over-represented in the brain drain.

This result is reinforced by the fact that emigration of highly skilled women is higher, the poorer is their origin country. This effect is also observed for men but to a lesser extent. It is not observed, however, at lower educational levels, where the traditional migration hump is identifiable.

The previous findings need also to be considered taking into account the key role played by women in the economic and social development of their country, and notably in human capital accumulation. Econometric estimates report a negative impact of emigration of highly skilled women on three key education and health indicators: infant mortality, under-5 mortality and secondary school enrolment rate by gender.

These results raise concerns about the potential impact of the female brain drain on the poorest countries. This is heightened by the fact that highly skilled immigrant women are more and more targeted in labour migration, especially in the domestic and caring sectors. In developing countries, this calls notably for offering women better opportunities to use their human capital. In other words, the gender dimension of the brain drain should be at the core of the on-going efforts to improve the policy coherence for development, notably through migration policies and aid policies. 


\section{References}

Barro R. J. and J.-W. Lee (2000), “International Data on Educational Attainment: Updates and Implications”, NBER Working Paper 7911.

Cogneau D. and F. Gubert (2005), "Migrations du sud et réduction de la pauvreté : des effets ambigus pour les pays de départ”, in Les nouvelles migrations : Un enjeu Nord-Sud de la mondialisation, Paris: Éditions Universalis.

Commander S., M. Kangasniemi and L. A. Winters (2004), "The Brain Drain: Curse or Boon? A Survey of the Literature”, in R. Baldwin and L. A. Winters (eds.), Challenges to Globalisation, Chicago: NBER and University of Chicago Press.

Docquier F., O. Lohest and A. Marfouk (2007, forthcoming), "Brain Drain in Developing Countries”, World Bank Economic Review.

Docquier F., and H. Rapoport, “Skilled Migration: The Perspective of Developing Countries”, IZA Discussion Paper No. 2873, Bonn, June.

Dumont J.-C. and O. Monso (2007), "Matching educational background and employment: a challenge for immigrants in host countries”, International Migration Outlook, Paris: OECD, pp. 131-159.

Dumont J.-C. and G. Lemaître (2005), "Beyond the Headlines: New Evidence on the Brain Drain”, Revue Économique, 56, pp. 1275-1300.

Ehrenreich B. and A. Hochschild (2002), Global Woman: Nannies, Maids and Sex Workers in the New Economy, New York: Metropolitan Press.

Hatton T. and J. Williamson (2006), Global Migration and the World Economy, Cambridge, MA: MIT Press.

Martin P. and J. E. Taylor (1996), “The Anatomy of a Migration Hump”, in J. E. Taylor (ed.), Development Strategy, Employment, and Migration: Insights from Models, Paris: OECD Development Centre.

OECD (2002), International Mobility of the Highly Skilled, Paris.

OECD (2006), International Migration Outlook $k_{2}$ Paris.

OECD (2007, forthcoming), "Immigrants in OECD countries: Demographic and Labour Market Characteristics by Detailed Place of Birth”, Paris.

Oso Casas L. and J.-P. Garson (2005), “Migrant women and the labour market: Diversity and challenges”, OECD and European Commission Seminar, Brussels, 26-27 September.

Parreñas R. (2001), Servants of Globalization: Women, Migration and Domestic Work, Stanford, CA: Stanford University Press.

Schultz T. P. (ed.) (1995), Investment in Women's Human Capital, Chicago: University of Chicago Press.

UNDP (2002), Human Development Report, New York and Oxford: Oxford University Press.

UNESCO (2004), EFA Global Monitoring Report 2003/04: Gender and Education for All, The Leap to Equality, Paris: UNESCO.

United Nations (2006), 2004 World Survey on the Role of Women in Development: Women and International Migration, New York: United Nations.

United Nations (2006), Trends in the Total Migrant Stock: The 2005 Revision (United Nations, POP/DB/MIG/Rev.2005), data in digital form.

Wils A. and A. Goujon (1998), "Diffusion of Education in Six World Regions, 1960-90", Population and Development Review, 24, 357-368. 
World Bank (2001), Engendering Development: Through Gender Equality in Rights, Resources, and Voice, Policy Research Report series, Washington, DC: World Bank.

World Bank (2007, forthcoming), Women in International Migration. 
ANNEX : Summary statistics

\begin{tabular}{|l|r|r|r|r|}
\hline Variable & Mean & $\begin{array}{l}\text { Std. } \\
\text { Dev. }\end{array}$ & Min & Max \\
\hline \multicolumn{5}{|l|}{} \\
\hline Sample including OECD countries \\
\hline $\log (\mathrm{GDPpC})$ & 8.4 & 1.1 & 6.1 & 10.2 \\
\hline $\log (P O P)$ & 16.3 & 1.6 & 12.5 & 21.0 \\
\hline Island & 0.2 & 0.4 & 0 & 1 \\
\hline English & 0.3 & 0.5 & 0 & 1 \\
\hline Spanish & 0.2 & 0.4 & 0 & 1 \\
\hline French & 0.2 & 0.4 & 0 & 1 \\
\hline$m_{\text {ieg }}$ & 0.1 & 0.1 & $2.0 E-04$ & 0.8 \\
\hline $\log \left(m_{\text {ieg }} /\left(1-m_{\text {ieg }}\right)\right)$ & -3.3 & 1.7 & -8.5 & 1.4 \\
\hline
\end{tabular}

\section{Sample of non-OECD countries (but including Mexico and Turkey)}

\begin{tabular}{|l|r|r|r|r|}
\hline $\log (\mathrm{GDPpc})$ & 7.9 & 0.9 & 6.1 & 9.8 \\
\hline $\log (P O P)$ & 16.2 & 1.6 & 12.5 & 21.0 \\
\hline Island & 0.2 & 0.4 & 0 & 1 \\
\hline English & 0.4 & 0.5 & 0 & 1 \\
\hline Spanish & 0.2 & 0.4 & 0 & 1 \\
\hline French & 0.2 & 0.4 & 0 & 1 \\
\hline$m_{\text {ieg }}$ & 0.1 & 0.1 & $2.0 E-04$ & 0.8 \\
\hline $\log \left(m_{\text {ieg }} /\left(1-m_{\text {ieg }}\right)\right)$ & -3.4 & 1.9 & -8.5 & 1.4 \\
\hline Infant mortality rate & 59.2 & 43.2 & 4.0 & 167.0 \\
\hline Under 5 mortality rate & 87.2 & 73.4 & 4.0 & 286.0 \\
\hline Male secondary enrollment rate & 61.1 & 25.3 & 6.4 & 101.5 \\
\hline Female secondary enrollment rate & 61.6 & 28.3 & 5.1 & 110.5 \\
\hline
\end{tabular}

